\title{
Paparan Limbah Cair Industri Mengandung Logam Berat pada Lahan Sawah di Desa Jelegong, Kecamatan Rancaekek, Kabupaten Bandung
}

\author{
Industrial Wastewater Containing Heavy Metal Exposures \\ on Paddy Field in Jelegong Village, Rancaekek District, \\ Bandung Regency
}

\author{
WAGE KOMARAWIDJAJA \\ Pusat Teknologi Lingkungan -Badan Pengkajian dan Penerapan Teknologi \\ Gedung Geostech 820, Puspiptek Serpong, Indonesia 15314 \\ wage.komarawidjaja@bppt.go.id
}

\begin{abstract}
The rice fields in Jelegong, Rancaekek district is one of the areas affected by the wastewater of the textile industry surounding. Therefore, this research is conducted in Jelegong village, which aims to examine the exposure of heavy metal content of textile industry waste in paddy fields. The analysis of soil samples from the rice fields shows that some heavy metals are detected in high concentrations. The high content of heavy metals is $\mathrm{Cr}(0.06-174.7 \mathrm{mg} / \mathrm{I})$, As $(0.28-4.0 \mathrm{mg} / \mathrm{I})$ and $\mathrm{Hg}(25.9-92.2 \mathrm{mg} / \mathrm{I})$, while the concentration Other heavy metals, $\mathrm{Pb}(0.05-11.7 \mathrm{mg} / \mathrm{I}), \mathrm{Cd}(0.02-0.17 \mathrm{mg} / \mathrm{I})$. Cr content of soil samples according to USEPA regulations are included in the slightly polluted category of sample points LS-04 (Cr 25,6mg / I), LS-03 (Cr 27,4mg / I), LS-02 (Cr 34,1 mg / I) And heavily polluted LS-01 ( $\mathrm{Cr} 174,7 \mathrm{mg} / \mathrm{I})$. While based on Thai soil for agriculture and Thai settlements, heavy metals $\mathrm{As}$ and $\mathrm{Hg}$ have exceeded the maximum permissible limits, for example LS-03 (As 4.0mg / I) and LS-04 (As 4,2mg / I) soils. While for $\mathrm{Hg}$ has exceeded the maximum permissible limit of LS-02 ( $\mathrm{Hg} \mathrm{25.9mg} \mathrm{/} \mathrm{I)} \mathrm{and} \mathrm{LS-01} \mathrm{(} \mathrm{Hg} 92.2 \mathrm{mg} / \mathrm{I})$ soil samples. Given the measured heavy metals concentration is the result of accumulation, So, eventhough, heavy metals are measured low, regular supervision must be undertaken
\end{abstract}

Keywords: textile industry, textile wastewater, heavy metal, paddy field

\begin{abstract}
ABSTRAK
Lahan persawahan di Jelegong, Kecamatan Rancaekek merupakan salah satu wilayah yang terkena dampak limbah cair kawasan Industri tekstil. Oleh karena itu, penelitian ini dilakukan di desa Jelegong, yang bertujuan mengkaji paparan kandungan logam berat limbah industri tekstil di lahan persawahan. Hasil analisa contoh tanah dari lahan persawahan tersebut, menunjukkan beberapa logam berat terdeteksi dalam konsentrasi yang cukup tinggi. Kandungan logam berat yang tinggi adalah $\operatorname{Cr}(0,06-174,7 \mathrm{mg} / \mathrm{l})$, As $(0,28-4,0 \mathrm{mg} / \mathrm{l}) \mathrm{dan}$ $\mathrm{Hg}(25,9-92,2 \mathrm{mg} / \mathrm{l})$, sementara konsentrasi logam berat yang lain, $\mathrm{Pb}(0,05-11,7 \mathrm{mg} / \mathrm{l}), \mathrm{Cd}(0,02-0,17$ $\mathrm{mg} / \mathrm{l})$. Kandungan $\mathrm{Cr}$ contoh tanah sawah menurut peraturan USEPA termasuk dalam kategori tercemar ringanpada titik sampel LS-4(Cr 25,6mg/l), LS-03(Cr 27,4mg/l), LS-02(Cr 34,1mg/l) dan tercemar beratpada LS-01(Cr 174,7mg/l). Sementara berdasarkan bakumutu lahan tercemar logam berat Thailand, As dan $\mathrm{Hg}$ telah melampaui batas maskimum yang diperbolehkan, dimana untuk contoh tanah LS-03 (As 4,0mg/l) dan LS-04(As 4,2mg/l), sedangkan untuk $\mathrm{Hg}$ telah melampaui batas maskimum yang diperbolehkan pada contoh tanah LS-02( $\mathrm{Hg} \mathrm{25,9mg/l)}$ dan LS-01( $\mathrm{Hg}$ 92,2mg/l).Mengingat konsentrasi logam berat yang terukur merupakan hasil akumulasi, maka meskipun beberapa kandungan logam berat terukur rendah, tetap harus dilakukan pengawasan yang teratur.
\end{abstract}

Kata kunci :industri tekstil, limbah cair tekstil, logam berat, lahan sawah 


\section{PENDAHULUAN}

\subsection{Latar Belakang}

Semula wilayah administrasi Kecamatan Rancaekek dikenal sebagai salah satu daerah lumbung padi di Timur Kota Bandung(Gambar-1). Sawah terhampar sejauh mata memandang, di sebelah selatan jalan raya Rancaekek. Namun sejak tahun 1980-an wilayah ini telah berubah fungsi, menjadi kawasan industri yang di dominasi oleh jenis industri tekstil ${ }^{(1)}$.

Perubahan tataguna lahan di wilayah Rancaekek ini selain ditandai oleh perkembangan kawasan industri juga diikuti oleh peningkatan jumlah kawasan permukiman dan kepadatan penduduk $^{(2)}$.

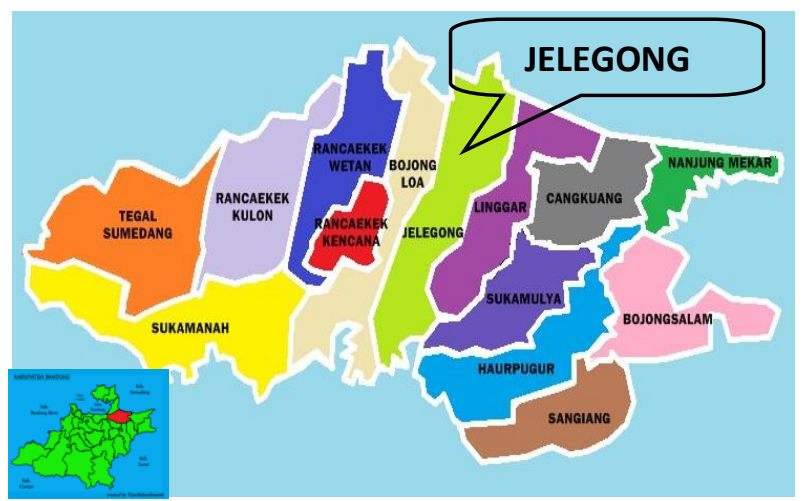

Gambar-1. Peta administrasi Desa Jelegong,

Kec. Rancaekek, Kab. Bandung ${ }^{(3,4)}$.

Dengan adanya kegiatan industri tersebut diharapkan mampu memberikan dampak positif bagi masyarakat sekitar Kecamatan Rancaekek, terutama terkait penyerapan tenaga kerja, khususnya bagi masyarakat sekitar dan umumnya bagi angkatan kerja Indonesia. Namun demikian dalam perkembangan industri tersebut, limbah cair yang timbul dalam proses produksi dibuang ke Sungai Cikijing tetapi tidak diolah dengan baik, sehingga menimbulkan pencemaran di empat desa di Kecamatan Rancaekek, diantaranya adalah Desa Linggar, Desa Jelegong, Desa Sukamulya dan Desa Bojongloa ${ }^{(1,4)}$.

Limbah cair industri yang dibuang ke Sungai Cikijing tersebut telah mencemari lahan pertanian dan sumber air bersih domestik yangdapatmenimbulkan degradasi lingkungan. Kondisi ini akan mengakibatkan penurunan produksi pertanian karena pengairan dari saluran irigasi yang dimanfaatkan di wilayah terebut berasal dari sungai Cikijingyang memasukikawasan industri dan selanjutnya mengalir menuju Desa Linggar dengan beban pencemaran yang terus meningkat, sebagaimana diungkapkan dalam laporan Kementerian Lingkungan Hidup ${ }^{(5)}$. Bahkan menurut BPLHD Jabar, sungai Cikijing termasuk kategori tercemar berat ${ }^{(5)}$.

Sementara beberapa laporan penelitian sebelumnya mengungkapkan bahwa, Sungai Cikijing selain tercemar berat juga terpapar logam berat dengan konsentrasi relatif tinggi, sebagaimana disajikan pada Tabel-1 dan Tabel-2. Lebih lanjut, hasil penelitian sebelumnya mengungkapkan adanya akumulasi pencemaran bahan berbahaya di sedimen sungai Cikijing ${ }^{(4,7,8)}$ dan bahkan pada tanaman padi di lahan persawahan telah tercemar ${ }^{(7)}$.

Tabel-1. Hasil analisis logam berat sampel air sungai cikijing di Rancaekek.

\begin{tabular}{clllll}
\hline Stasiun & \multicolumn{5}{c}{ Logam Berat (mg/l) } \\
\cline { 2 - 6 } & $\mathrm{Cd}$ & $\mathrm{Cr}$ & $\mathrm{Pb}$ & $\mathrm{As}$ & $\mathrm{Zn}$ \\
\hline$(1)$ & $<0.005$ & 0.07 & $<0.05$ & 0.05 & 0.04 \\
\hline$(2)$ & $<0.005$ & $<0.02$ & $<0.05$ & 0.04 & $<0.005$ \\
\hline$(3)$ & - & $<0.02$ & $<0.05$ & 0.05 & $<0.005$ \\
\hline
\end{tabular}

Sumber : Komarawidjaja, $2016^{(4)}$

Tabel-2. Hasil analisis logam berat air sungai di Rancaekek.

\begin{tabular}{cccccc}
\hline Cr6+ & $\mathrm{Zn}$ & $\mathrm{Cd}$ & $\mathrm{Pb}$ & $\mathrm{Hg}$ & $\begin{array}{c}\text { Baku } \\
\text { Mutu }\end{array}$ \\
\hline$(\mathrm{mg} / \mathrm{L})$ & $(\mathrm{mg} / \mathrm{L})$ & $(\mathrm{mg} / \mathrm{L})$ & $(\mathrm{mg} / \mathrm{L})$ & $(\mathrm{ppb})$ & - \\
\hline 0.008 & 0.124 & 0.0005 & 1.38 & 0.22 & - \\
\hline 0.05 & 0.05 & 0.01 & 0.03 & 0.001 & $\mathrm{BM} \mathrm{I}$ \\
\hline 0.05 & 0.05 & 0.01 & 0.03 & 0.002 & $\mathrm{BM} \mathrm{II}$ \\
\hline 0.05 & 0.05 & 0.01 & 0.03 & 0.002 & $\mathrm{BM} \mathrm{III}$ \\
\hline 0.01 & 2 & 0.01 & 1 & 0.005 & $\mathrm{BM} \mathrm{IV}$ \\
\hline \multicolumn{5}{l}{ Sumber : Birry, dan Meutia, $2016\left({ }^{(7)}\right.$}
\end{tabular}

Limbah logam berat dari industry tekstil terutama berasal dari berasal dari zat pewarnaan. Limbah logam berat yang dihasilkan antara lain : logam berat arsen (As), kadmium (Cd), krom (Cr), timbal $(\mathrm{Pb})$, tembaga $(\mathrm{Cu})$, seng $(\mathrm{Zn})$. Penyebab zat warna mengandung logam berat. pertama digunakan sebagai katalis selama proses pembuatan zat warna, kedua, sebagian zat warna mempunyai logam didalamnya sebagai bagian dari molekul zat warna tersebut, sebagaimana disajikan pada Tabel- $3^{(9)}$. 
Dengan mempertimbangkan terdeteksinya logam berat pada sampel air sungai Cikijing dan sedimen serta contoh tanah sempadan sungai, maka dilakukan penelitian terhadap keberadaan logam berat pada lahan pertanian di desa Jelegong, Kecamatan Rancaekek.

Tabel-3. Jenis logam berat pada zat warna tekstil.

\begin{tabular}{ll}
\hline Jenis zat warna & $\begin{array}{l}\text { Jenis logam dalam } \\
\text { Struktur Zat Warna }\end{array}$ \\
\hline Direk & $\mathrm{Cu}$ \\
\hline Reaktif & $\mathrm{Cu}, \mathrm{Ni}$ \\
\hline Bejana & Tidak ada \\
\hline Disperse & Tidak ada \\
\hline Asam & $\mathrm{Cu}, \mathrm{Cr}, \mathrm{Co}$ \\
\hline Premet & $\mathrm{Cu}, \mathrm{Cr}, \mathrm{Co}$ \\
\hline Mordan & $\mathrm{Cr}$ \\
\hline Pigmen & $\mathrm{Pb}, \mathrm{Cr}, \mathrm{Mo}, \mathrm{Cd}$ \\
\hline Sumber : Kurniasih, $2008^{(9)}$.
\end{tabular}

\subsection{Tujuan}

Penelitian ini bertujuan untuk mendalami paparan, akumulasi logam berat dari limbah cair industri pada lahan pertanian. Apakah dengan semakin jauh jarak dari sumber limbah logam berat (sungai Cikijing), maka semakin rendah tingkat akumulasinya di lahan pertanian.

\section{BAHAN DAN METODE}

\subsection{Tempat Penelitian}

Penelitian ini dilaksanakan di lahan pertanian desa Jelegong, Kec. Rancaekek, Kabupaten Bandungyang terletak di dataran paling rendah di Kecamatan tersebut. Sementara lahan pertanian Desa ini mendapat pasokan pengairan dari aliran Sungai Cikijing setelah melewati kawasan Industri Tekstil, sehingga limpasan air dari sungai Cikijing yang diduga tercemar akan mengalir ke wilayah ini.

\subsection{Logam Berat Tanah yang Diukur}

Contoh tanah diambil dari beberapa titik sampel lahan sawah (LS), yaitu LS-01, LS-02, LS03, dan LS-04 dengan titik koordinat sampel disajikan pada Tabel-4 dan peta lokasi pengambilan contoh tanah Gambar-2. Contoh tanah diambil 2 periode yang mewakili musim kering dan penghujan. Selanjutnya contoh tanah diukur kandungan logam berat kadmium (Cd), kromium $(\mathrm{Cr})$, timah hitam $(\mathrm{Pb})$, arsen $(\mathrm{As})$ dan seng $(Z n)$.

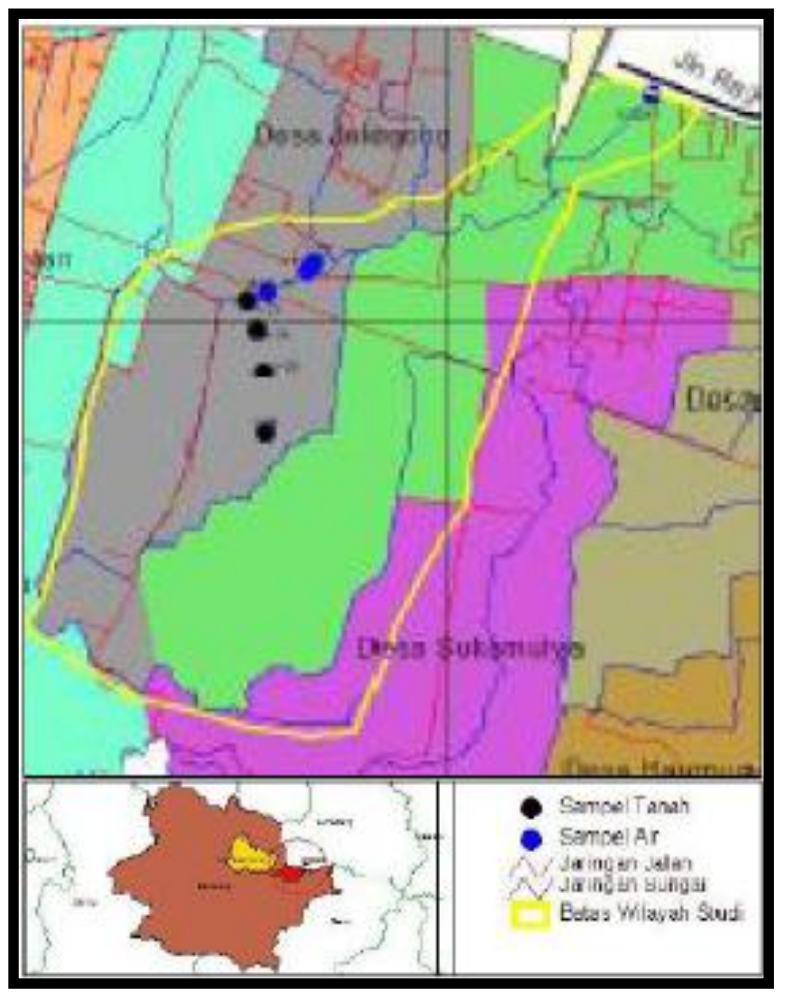

Gambar-2. Lokasi penelitian di Desa Jelegong di Kec. Rancaekek Kab. Bandung,

Tabel-4. Koordinat titik pengambilan contoh tanah di Desa Jelegong, Rancaekek

\begin{tabular}{ccc}
\hline No & Lat & Long \\
\hline LS-01 & 806306 & 9228509 \\
\hline LS-02 & 806354 & 9228348 \\
\hline LS-03 & 806389 & 9228117 \\
\hline LS-04 & 806401 & 9227792 \\
\hline
\end{tabular}




\section{HASIL DAN PEMBAHASAN}

\subsection{Kandungan Logam Berat Lahan Persawahan Desa Jelegong}

Secara umum, dalam suatu proses produksi suatu industri, digunakan kelompok bahan baku produksi yang dikenaldenganistilah bahan baku utama dan bahan baku penunjang. Bahan baku tersebut, adakalanya mengandung logam berat, sehingga limbah yang dihasilkan industri tersebut mengandung unsur-unsur yang sama seperti bahan bakunya, sebagaimana disajikan pada Tabel-5. ${ }^{(10)}$ Limbah industri yang mengandung logam berat yang masuk ke dalam badan air, akan membahayakan pengguna sungai tersebut.

Dikawatirka npenggunaan air sungai yang mengandung limbah logam berat terus menerus, lambat laun akan terjadi akumulasi dalam tanah dan tanaman di atasnya. Hasil kajian sebelumnya yang disajikan pada Tabel-1 dan Tabel-2 menguatkan bahwa limbah industri di kawasan Rancaekek mengandung logam berat, antara lain $\mathrm{Cd}, \mathrm{Cr}, \mathrm{Pb}$ dan $\mathrm{Hg}^{(4,7)}$.

Tabel-5. Beberapa jenis industri mengandung limbah logam berat $^{(10) .}$.

\begin{tabular}{cccccc}
\hline \multirow{2}{*}{ No. } & Jenis & \multicolumn{5}{c}{ Jenis Industri } \\
& Logam & 1 & 2 & 3 & 4 \\
\hline 1 & $\mathrm{Hg}$ & + & + & + & - \\
2 & $\mathrm{~Pb}$ & + & - & + & + \\
3 & $\mathrm{Cd}$ & - & + & - & + \\
4 & $\mathrm{Cr}$ & - & + & + & - \\
5 & $\mathrm{Cu}$ & - & + & - & + \\
6 & $\mathrm{Zn}$ & + & + & - & + \\
7 & $\mathrm{Ni}$ & - & - & - & - \\
8 & $\mathrm{Mn}$ & - & - & - & - \\
9 & $\mathrm{Co}$ & - & + & - & - \\
\hline \multicolumn{5}{l}{ Keterangan : 1= Farmasi, 2=Tekstil, 3=Pulp, dan 4=Pestisida }
\end{tabular}

Hasil pemeriksaan laboratorium terhadap kandungan logam berat pada contoh tanah, lahan persawahan desa Jelegong, sebagaimana disajikan pada Tabel-6, menunjukkan pola yang beragam. Ada jenis logam berat yang semakin menjauhi sumber pencemar (Sungai Cikijing) semakin meningkat konsentrasinya sehingga patut diduga telah terjadi proses akumulasi pada titik kordinat contoh tanah, tetapi diperoleh juga konsentrasi logam berat yang semakin menurun.

Beberapa logam berat yang memiliki sifat akumulatif dan karsinogenik, yang terpapar kedalam lingkungan produktif seperti lahan pertanian, lahan persawahan, sangat membahayakan kehidupan, misalnya logam berat yang terakumulasi di lahan pertanian, akan masuk kedalam sel tanaman yang merupakan pakan hewan dan pangan bagi kehidupan manusia, akan sangat membahayakan.

Tabel-6. Data hasil pengukuran kandungan logam berat sampel lahan sawah Desa Jelegong

\begin{tabular}{lccccc}
\hline $\begin{array}{l}\text { NO. } \\
\text { Contoh }\end{array}$ & $\begin{array}{c}\text { Pb } \\
\mathbf{p p m}\end{array}$ & $\begin{array}{c}\text { Cd } \\
\mathbf{p p m}\end{array}$ & $\begin{array}{c}\mathbf{C r} \\
\mathbf{p p m}\end{array}$ & $\begin{array}{c}\mathbf{A s} \\
\mathbf{p p m}\end{array}$ & $\begin{array}{c}\mathbf{H g} \\
\mathbf{p p m}\end{array}$ \\
\hline Periode I & & & & & \\
\hline LS-01 & 0.9 & 0.17 & 174.7 & 3.9 & 92.2 \\
LS-02 & 9.7 & 0.13 & 34.1 & 3.7 & 25.9 \\
LS-03 & 11.7 & 0.15 & 27.4 & 4.0 & $\mathrm{td}$ \\
LS-04 & 10.5 & 0.08 & 25.6 & 4.2 & 12.3 \\
\hline Periode II & & & & & \\
\hline LS-01 & 0.05 & 0.002 & 0.37 & td & td \\
LS-02 & 0.20 & 0.014 & 0.06 & 0.28 & td \\
LS-03 & 0.05 & 0.007 & 0.06 & 0.68 & $\mathrm{td}$ \\
LS-04 & 0.05 & td & td & td & td \\
\hline
\end{tabular}

Paparan logam berat di lahan pertanian dapat menimbulkan gangguan proses biologi termasuk proses-proses katalisasi oleh mikroorganisme. Namun, gangguan terhadap proses katalisasi mikroba tersebut dapat digunakan sebagai indikator perubahan kualitas tanahyang diakibatkan oleh paparan logam berat.

Upaya untuk melakukan penanganan limbah logam berat atau limbah B3 dari sumber-sumber industri dirasakan tidak mudah, tidak hanya di negara berkembang seperti Indonesia. Amerika Serikat misalnya sebagai negara maju, baru 10 persen dari jumlah limbah organik yang dibuang ke lingkungan secara aman. Padahal banyak sekali jenis limbah yang mengandung logam berat dan B3 digunakan dalam kegiatan industri, seperti senyawa berbahaya yang banyak digunakan dalam aktifitas rumah tangga, indsutri dan pertanian, seperti polisiklik aromatik $(\mathrm{PAH})$, pentachlorofenol (PCP), polychlorinated bifenil (PCB), 1,1,1-trichloro-2, 2-bis(4-chlorophenyl) ethane (DDT), benzene, toluene, dan ethylbenzene ${ }^{(11)}$.

\subsection{Perjalanan Logam Berat dalam Tanah}

Secara alami tanah mengandung berbagai unsur logam, unsur logam dominan adalah silikon (Si), aluminium $(\mathrm{Al})$, besi $(\mathrm{Fe})$, kalsium $(\mathrm{Ca})$, natrium $(\mathrm{Na})$, kalium $(\mathrm{K})$, dan magnesium $(\mathrm{Mg})$. Unsur-unsur logam pada tanah ini berasal dari 
pelapukan batu-batuan (batuan induk) dan keberadaan unsur ini akan besar pengaruhnya terhadap sifat fisik dan kimia tanah ${ }^{(12)}$. Sedangkan jenis logam berat, jika jumlahnya berlebih (sifatnya akumulatif) akan menjadi pencemar tanah.

Publikasi lain mengungkapkanbahwa, logam berat dalam tanah terdiri atas berbagai bentuk, seperti bentuk yang terikat pada partikel organik, bentuk tereduksi (hidroksida), bentuk karbonat, bentuk sulfida dan bentuk terlarut dalam tanah. Logam berat dimasukkan sebagai zat pencemar karena sifatnya yang stabil dan sulit untuk diuraikan ${ }^{(13)}$. Logam berat dalam tanah yang membahayakan pada kehidupan organisme dan lingkungan adalah dalam bentuk terlarut.

Secara umum, kation logam berat lebih banyak bergerak dalam kondisi asam. Proses kimia terpenting yang mempengaruhi perilaku dan ketersediaan logam berat dalam tanah berkaitan dengan adsorpsi logam berat dari fase cair ke fase padat. Proses-proses ini mengontrol konsentrasi ion logam berat dan menjadi kompleks dalam tanah sehingga berpengaruh terhadap penyerapan logam berat oleh akar tanaman $^{(12)}$.

Selanjutnya ada pendapat yang mengungkapkan bahwa, terdapat mekanisme yang bisa menjelaskan proses adsorpsi ion logam berat dalam tanah, yaitu pertukaran kation/ cation exchange (non-specific adsorption) dan adsorpsi spesifik (specific adsorption). Dalam hal ini pertukaran kation berarti pertukaran antara kationlogam berat dengan anion koloid tanah. Kebanyakan logam berat bertahan sebagai kation dalam tanah dan kemampuan adsorpsinya tergantung dari densitas muatan negatif (anion) pada permukaan koloid tanah. Untuk menjaga keelektronetral-an, maka muatan negatif permukaan diimbangi oleh kation dengan jumlah yang sama ${ }^{(12)}$. Hal tersebut diperkuat oleh hasil penelitian oleh Wild (1993), logam berat dalam tanah umumnya berbentuk kation (ion positif) dan akan diikat oleh anion (ion-ion negatif) dari partikel tanah. Adsorpsi spesifik merupakan pertukaran kation logam berat dan kebanyakan anion dengan ligand permukaan untuk membentuk sebagian ikatan kovalen ${ }^{(14)}$.

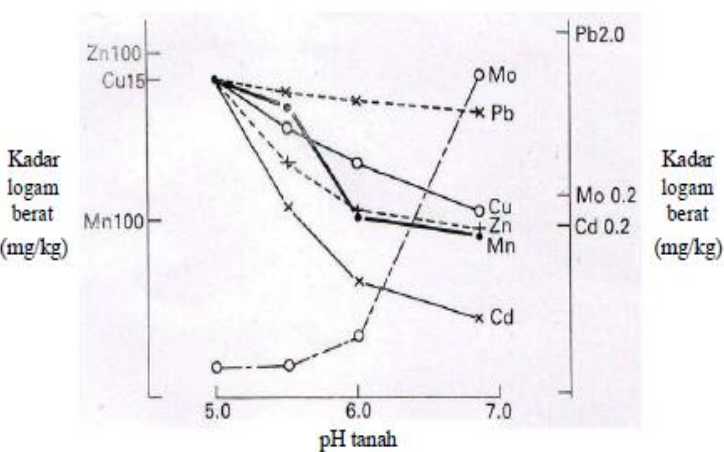

Gambar-3. Hubungan antara $\mathrm{pH}$ tanah dan kadar logam yang terkandung Sumber : Wild (1993) ${ }^{(14)}$

Efek toksik logam berat lebih ditentukan oleh bentuknya daripada konsentrasinya ${ }^{(15)}$. Bentuk ion utama Cd dalam tanah adalah $\mathrm{Cd}^{2+}$ tapi bisa juga membentuk ion kompleks seperti $\mathrm{CdCl}^{+}$, $\mathrm{CdOH}^{+}, \mathrm{CdHCO}_{3}{ }^{+}, \mathrm{CdCl}_{3}{ }^{-}, \mathrm{CdCl}_{4}{ }^{2-}, \mathrm{Cd}(\mathrm{OH})_{3}{ }^{-}$dan $\mathrm{Cd}(\mathrm{OH})_{4}{ }^{2-}$. $\mathrm{Cd}$ cenderung lebih mobil dalam tanah sehingga lebih tersedia untuk tanaman. Sama seperti $\mathrm{Cu}$, jika $\mathrm{pH}$ menurun maka kadar Cd akan cenderung meningkat. Logam $\mathrm{Zn}$ diketahui memiliki efek antagonistik terhadap penyerapan $\mathrm{Cd}$ dalam tanah artinya adanya $\mathrm{Zn}$ bisa mengurangi keberadaan Cd dalam tanah ${ }^{(12)}$.

Ketersediaan $\mathrm{Cu}$ dalam tanah yang bisa diserap tanaman berada dalam bentuk ion $\mathrm{Cu}^{2+}$. Biasanya konsentrasi $\mathrm{Cu}$ dalam tanaman berada pada rentang 5-20 mg/kg. Akumulasi Cu berbedabeda pada tanaman tergantung spesies dan kultivarnya. Ion-ion yang bisa mengurangi penyerapan $\mathrm{Cu}$ adalah $\mathrm{Ca}^{2+}, \mathrm{K}^{+}$dan $\mathrm{NH}_{4}^{+}$. Pergerakan dan ketersediaan $\mathrm{Cu}$ dalam tanah sangat dipengaruhi oleh $\mathrm{pH}$ tanah, kandungan bahan organik, keberadaan unsur besi $(\mathrm{Fe})$, mangan $(\mathrm{Mn})$ dan alumunium oksida. Sementara penurunan $\mathrm{pH}$ justru akan meningkatkan penyerapan $\mathrm{Cu}^{2+}$ oleh akar tanaman karena penurunan $\mathrm{pH}$ akan meningkatkan aktivitas $\mathrm{Cu}^{2+}$. Logam berat $\mathrm{Cu}$ relatif tidak mobil dalam tanaman $^{(12)}$. Pengaruh $\mathrm{pH}$ tanah terhadap kadar logam berat disajikan pada Gambar-3. 


\subsection{Status Logam Berat di Lahan Persawahan Jelegong}

Berdasarkan acuan bakumutu untuk logam berat $\mathrm{Cr}$ menurut peraturan dari USEPA (Tabel-7) tentang kandungan logam berat dalam suatu sedimentelah melampaui batas maskimum yang diperbolehkan untuk persawahan di desa Jelegong termasuk dalam kategori tercemar ringan sampai berat ${ }^{(16)}$., serta menurut bakumutu tanah untuk pertanian dan pemukiman di Thailand (Tabel-8), kandungan As dan $\mathrm{Hg}$ telah melebihi ambang batas ${ }^{(17)}$.

Menurut dua referensi bakumutu tersebut, kondisi tanah dengan kandungan logam berat seperti disajikan pada Tabel-6 sudah sangat membahayakan lingkungan.

Indonesia sampai saat ini belum memiliki bakumutu untuk tanah terkontaminasi logam berat, namun Indonesia pada tahun 1992 bekerjasama dengan Canada melakukan penyusunan batas kritis logam berat pada tanah untuk beberapa logam berat, seperti $\mathrm{Pb}, \mathrm{Cd}, \mathrm{Cr}$, $\mathrm{Co}, \mathrm{Cu}, \mathrm{Ni}, \mathrm{Mn}$ dan $\mathrm{Zn}{ }^{(18)}$. Membandingkan dengan batas kritis logam berat tersebut, $C d$ dan $\mathrm{Cr}$ telah melampaui batas kritis logam berat dalam tanah.

\section{Logam Timah Hitam, Plumbum(Pb)}

Logam $\mathrm{Pb}$ ternyata menunjukkan suatu kenyataan yang sangat mengagetkan dan nilainya ternyata semakin jauh dari sumber pencemar semakin membesar, atau terakumulasi, padahal pada lokasi terakhir tersebut dijumpai tanaman cattail yang semestinya bisa mengikat logam $\mathrm{Pb}$ sehingga tidak tersedia dalam tanah.
Nilaianalisamenunjukankisaranantara $\quad 0,9$ ppm hingga 11,7 ppm (Gambar-4), nilai konsentrasi Pb tersebut tidak melampaui bakumutu, namun dengan kecenderungan semakin meningkat dengan semakin jauh dari titik LS-01, dikawatirkan lambat laun akan semakin meningkat akibat terjadi akuulasi pada jaringan tanah.

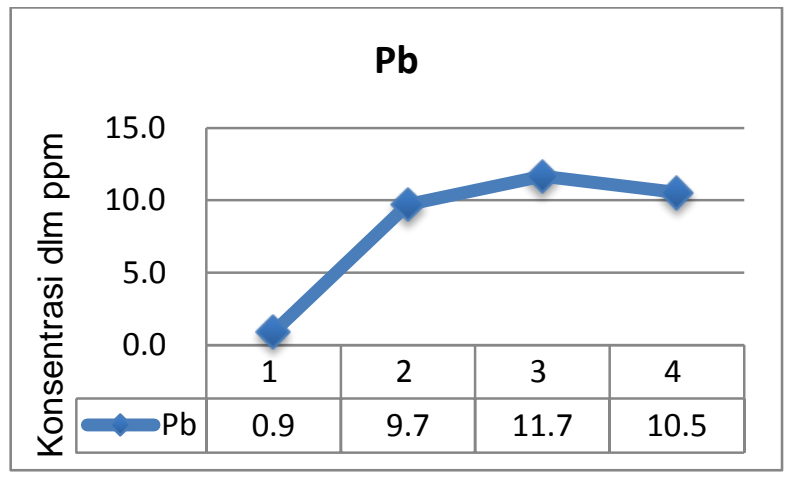

Gambar 4. Konsentrasi Timah Hitam (Pb)

\section{Logam Cadmium (Cd)}

Logam Cd ternyata di sumber konsentrasinya kecil atau sedikit, namun dalam kenyataannya bahwa semakin menjauh terlihat adanya akumulasi. Kecenderungan ini hampir mirip dengan pola sebaran logam $\mathrm{Pb}$, walaupun tidak sama persis. Kisaran kandungan Kadmium pada lokasi studi antara 0,08 ppm s /d 0,17 ppm (Gambar-5), konsentrasi ini belum melampaui baku mutu ${ }^{(16,17)}$.

Tabel-7. Baku mutu kandungan logam berat dalam sedimen dari USEPA.

\begin{tabular}{ccccc}
\hline $\begin{array}{c}\text { Unsur Logam } \\
\text { Berat }\end{array}$ & $\begin{array}{c}\text { Tidak } \\
\text { Tercemar }\end{array}$ & $\begin{array}{c}\text { Tercemar } \\
\text { Ringan }\end{array}$ & $\begin{array}{c}\text { Tercemar } \\
\text { Berat }\end{array}$ & $\begin{array}{c}\text { Rata-rata dalm } \\
\text { kerak Bumi }\end{array}$ \\
\hline $\mathrm{Pb}$ & $<40$ & $40-60$ & $>60$ & 16 \\
$\mathrm{Zn}$ & $<90$ & $90-200$ & $>200$ & 80 \\
$\mathrm{Fe}$ & $<17000$ & $17000-25000$ & $>25000$ & 50000 \\
$\mathrm{Ni}$ & $<20$ & $20-50$ & $>50$ & 100 \\
$\mathrm{Mn}$ & $<300$ & - & $>500$ & 1000 \\
$\mathrm{Cd}$ & - & - & $>6$ & 0,2 \\
$\mathrm{Cr}$ & $<25$ & $25-75$ & $>75$ & 200 \\
$\mathrm{Cu}$ & $<25$ & $25-50$ & $>50$ & 70 \\
\hline
\end{tabular}


Tabel 8. Baku mutu tanah untuk pertanian dan pemukiman negara Thailand. ${ }^{(17)}$

\begin{tabular}{llc}
\hline No. & Jenis Logam Berat & $\begin{array}{c}\text { Baku Mutu } \\
(\mathrm{mg} / \mathrm{kg})\end{array}$ \\
\hline 1 & Arsen (As) & 3,9 \\
2 & Cadmium $(\mathrm{Cd})$ & 37 \\
3 & Lead $(\mathrm{Pb})$ & 400 \\
4 & Mercury $(\mathrm{Hg})$ & 23 \\
\hline
\end{tabular}

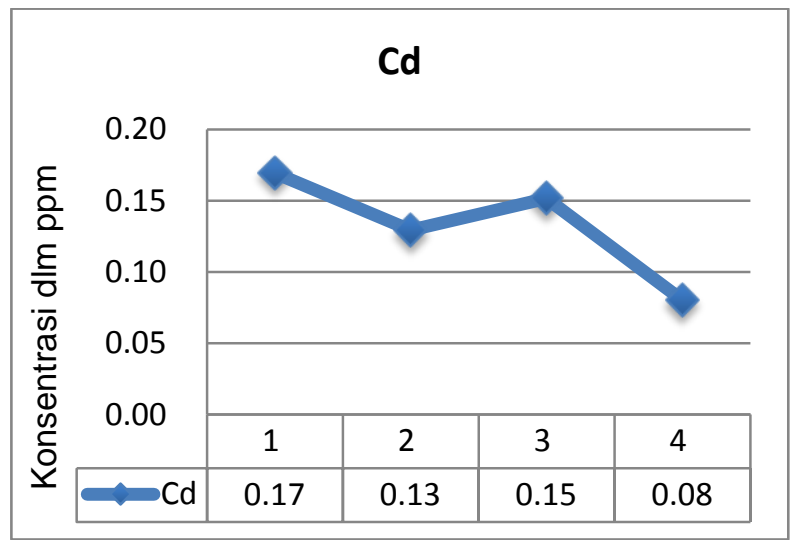

Gambar-5. Konsentrasi Cadmium (Cd)

\section{Logam Chromium (Cr)}

Logam $\mathrm{Cr}$ konsentrasinya tinggi sekali di lokasi studi terutama pada sumber pencemar, namun demikian kecenderungan menunjukkan bahwa semakin menjauh dari sumber logam $\mathrm{Cr}$ kadarnya semakin mengecil. Pola sebaran logam Cr mirip dengan pola sebaran logam Ni dan Co. Kisaran kandungan logam $\mathrm{Cr}$ dalam tanah lokasi studi adalah antara 25,6 ppm s/d 174,7 ppm. Jadi ternyata bahwa air buangan limbah tekstil banyak mengandung logam $\mathrm{Cr}$. Oleh karena itu perlu adanya tindakan pencegahan pada sumber agar konsentrasi logam $\mathrm{Cr}$ tidak melimpah pada badan air, bila tidak akan sangat menghawatirkan bagikesehatan dan keberlangsungan hidup penduduk setempat dan mahluk hidup lainnya (Gambar-6).

Bandingkan dengan baku mutu khusus untuk logam berat. Berdasarkan acuan bakumutu USEPA (Tabel-7) kandungan logam berat $\mathrm{Cr}$ dalam sedimen persawahan desa Jelegongtelah melampaui batas maskimum yang diperbolehkan dan termasuk dalam kategori tercemar ringan sampai berat ${ }^{(16)}$.,

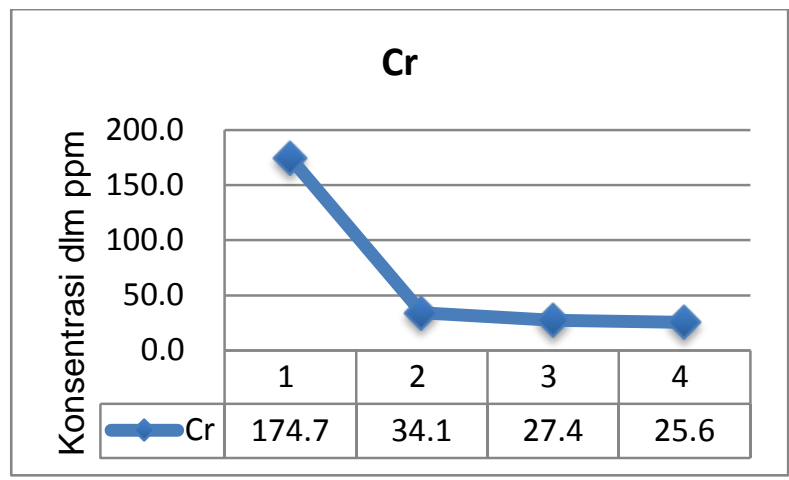

Gambar-6. Konsentrasi Chromium (Cr)

\section{Logam Arsen (As)}

Logam As konsentrasinya di sumber cukup besar dan ada kecenderungan meningkat sejalan dengan perjalanan menjauh dari sumber. Pola sebaran logam As mirip dengan pola sebaran logam $\mathrm{Pb}$ dan $\mathrm{Cd}$. Kisaran kandungan logam As adalah sebesar 3,7 ppm hingga 4,2 ppm (Gambar-7). Menurut baku mutu tanah untuk pertanian dan pemukiman Thailand (Tabel-8), kandungan As telah melebihi ambang batas ${ }^{(17)}$.

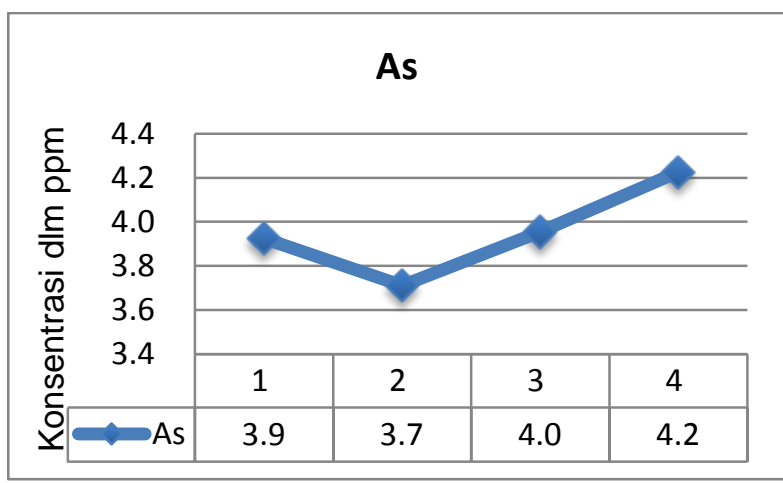

Gambar-7. Konsentrasi Arsen (As)

\section{Logam Air Raksa (Hg)}

Logam $\mathrm{Hg}$ pada lokasi studi juga sangat menghawatirkan terutama pada sumber pencemar. Hal ini membuktikan sekali lagi bahwa limbah buangan tekstil sangat berbahaya bagi kehidupan biota, terutama masyarakat sekitar lokasi studi. Walaupun ada kecenderungan konsentrasi yang menurun sejalan dengan perjalanan menjauh dari sumber, namun kadar atau konsentrasinya pada air limbah industri tekstil sangat besar (Gambar-8). 


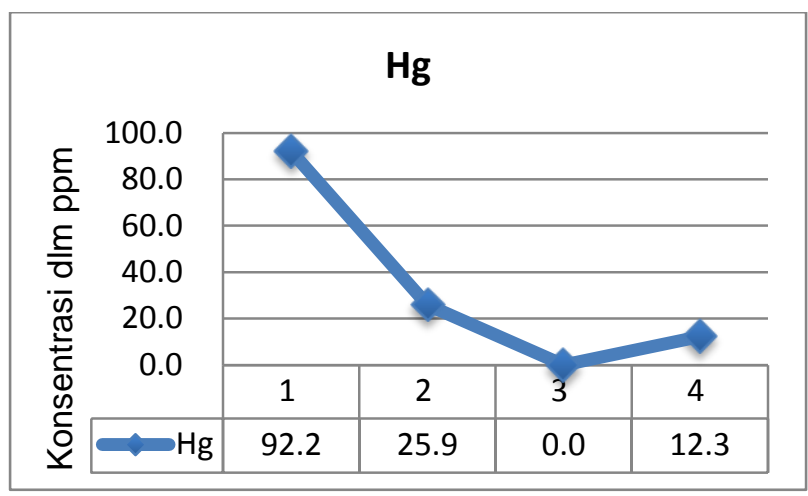

Gambar-8. Konsentrasi Air Raksa (Hg)

Kandungan logam $\mathrm{Hg}$ pada lokasi studi berkisar antara 12,3 ppm s/d 92,2 ppm. Konsentrasi $\mathrm{Hg}$ tersebut, menurut baku mutu tanah untuk pertanian dan pemukiman Thailand (Tabel8), telah melebihi ambang batas ${ }^{(17)}$.

\section{KESIMPULAN}

Dari hasil analisa contoh tanah, beberapa logam berat terdeteksi dalam konsentrasi tinggi $\mathrm{Cr}$ $(174,7 \mathrm{mg} / \mathrm{l})$, As $(4,0 \mathrm{mg} / \mathrm{l})$ dan $\mathrm{Hg}(92,2$ $\mathrm{mg} / \mathrm{l})$.Menurut peraturan USEPA, kandungan $\mathrm{Cr}$ contoh tanah sawah kategori tercemar ringan adalah titik sampel LS-04(Cr 25,6mg/l), LS-03(Cr $27,4 \mathrm{mg} / \mathrm{l})$, LS-02(Cr 34,1 $\mathrm{mg} / \mathrm{l})$ dan yang tercemar berat LS-01(Cr 174,7mg/l). Sedangkan menurut bakumutu tanah untuk pertanian ${ }^{(16)}$, logam berat yang telah melampaui batas maskimum adalah As dan $\mathrm{Hg}$.

Untuk logam berat As, contoh tanah yang telah melampaui bakumutu adalah LS-03 (As 4,0mg/l) dan LS-04(As 4,2mg/l), sementara untuk $\mathrm{Hg}$ adalah LS-02(Hg 25,9mg/l) dan LS-01( $\mathrm{Hg} \quad 92,2 \mathrm{mg} / \mathrm{l})$. Namun demikian, meskipun konsentrasi logam berat yang terukur rendah, tetapi karena logam berat dalam tanah menunjukkan adanya proses akumulasi, maka pengelolaan dan pengawasan harus dilakukan secara teratur.

Dari jenis logam berat yang dianalisa, faktor jarak dari sumber paparan tidak memiliki pengaruh yang sama terhadap terjadinya peningkatan atau penurunan akumulasi dalam tanah. Beberapa hal yang mempengaruhi terjadinya akumulasi, antara lain jenis tanah, $\mathrm{pH}$ tanah, dan senyawa pengikat logam-logam berat yang tersedia dalam tanah tersebut.

\section{PERSANTUNAN}

Pertama, ucapan terima kasih disampaikan kepada pihak BPLHD Jabar yang telah memfasilitasi kegiatan penelitian lapang di daerah Rancaekek. Kedua, ucapan terima kasih disampaikan kepada
Profesor Dr. Ir. Yudhi S. Garno, yang telah memberikan arahan sehingga penulisan naskah dapat terwujud. Ketiga, ucapan terima kasih disampaikan kepada beberapa kolega yang tidak dapat penulis sebutkan satu persatu, yang telah mendukung terlaksananya penelitian dan penyusunan naskahnya.

\section{DAFTAR PUSTAKA}

1. Ummi, N. S. D. dan L. S. Akliyah, (2016), Kajian Dampak Pencemaran Air Limbah Industri Terhadap Kondisi Fisik Lingkungan, Sosial-Ekonomi Masyarakat Kecamatan Rancaekek Kabupaten Bandung. (The Study of Industrial Water Pollution Impact toward The Physical Environment and Social-Economic at Rancaekek Residence Kabupaten Bandung). Prosiding Perencanaan Wilayah dan KotaVolume 2, No.2:167-175. ISSN: 24606480 ,

2. Anonimus,(2008), Perda Kabupaten Bandung No.3 Tahun 2008 pasal 83 ayat tentang RTRW, Kabupaten Bandung.

3. Anonimus, (2016), Kecamatan Rancaekek Dalam Angka 2016. BPS - Kabupaten Bandung,

4. Komarawidjaja, W., (2016), Sebaran Limbah Cair Industri Tekstil Dan Dampaknya Di Beberapa Desa Kecamatan Rancaekek Kabupaten Bandung, Jurnal Teknologi Lingkungan (JTL) Vol 17, No.2 : 118-125. PISSN 1441-318X, e-ISSN 2548-6101

5. Anonimus,(2013), Laporan Verifikasi Sengketa Lingkungan Hidup Akibat Pembuangan Limbah ke Sungai Cikijing, Kementerian Lingkungan Hidup,

6. Anonimus, (2014), Laporan Hasil Uji, UUPT Laboratorium Lingkungan BPLH Kab. Bandung, Kabupaten Bandung.

7. Birry, A.A. dan H. Meutia, (2016), Konsekuensi Tersembunyi : Valuasi Kerugian Ekonomi Akibat Pencemaran Industri, http://www.greenpeace.org/

seasia/id/PageFiles/724033/Laporan\%20Melaw an\%20Limbah.pdf. Diunduh 09 Februari 2017.

8. Andarani, P. Roosmini, D., (2009), Profil Pencemaran Logam Berat (Cu, Cr, dan Zn) pada Air Permukaan dan Sedimen di Sekitar Industri Tekstil PT X (Sungai Cikijing), Faculty of Civil and Environmental Engineering, ITB. 
9. Kurniasih, Y.A., (2008), Fitoremediasi Lahan Pertanian Tercemar Logam Berat Kadmium Dan Tembaga Dari Limbah Industri Tekstil, Skripsi, Departemen Teknik Pertanian Fakultas Teknologi Pertanian, Institut Pertanian Bogor. $60 \quad$ hal. https://core.ac.uk/download/pdf/32348987.pdf. Diunduh 14-11-2016

10. Anonimus, (2000), Pengkajian Baku mutu Tanah pada Lahan Pertanian. Laporan Akhir Kerjasama Antara Proyek Pengembangan Penataan Lingkungan Hidup Badan Pengendalian Dampak Lingkungan Jakarta dan Pusat Penelitian Tanah dan Agroklimat Badan Litbang Pertanian, No. 50/Puslittanak/2000, (Tidak dipublikasikan)

11. Anonymous, (1992), Water Quality Assesments, Edited by Chapman and Hall Ltd. London. 585p UNESCO/WHO/UNEP.

12. Alloway, B.J., (1995), Heavy Metals in Soils, Second Edition, Blackie Academic \& Professional. An Imprint of Chapman \& Hall. Glasgow.

13. Yaron, B., R. Calvet and R. Prost., (1996), Soil Pollution, Processes and Dynamics. Springer. New York.

14. Wild, A., (1993), Soils and the Environment, Cambridge University Press, Cambridge. www.portaliptek.co.id. 2007, Jakarta.
15. Endrinaldi, (2010), LogamLogamBeratPencemarLingkungandanEfekTerh adapManusia, Jurnal ${ }^{\circ}$ KesehatanMasyarakat, September 2009 - Maret 2010, Volume 4, Nomor 1, hal : 42-46

16. Sawyer, C. N. and McCarty, P.L., (1978), Chemistery for Enviromental Engineering, Third edition, McGraw-Hill Book Company. Tokyo. $532 p$

17. Annonymous, (No-year), Soil Quality Standard, Pollution Control Department (PCD), Ministry of Natural Resource and Environment, Tahiland. http://www.pcd.go.th/info_serv/en_reg_std_soil 01.html\#s1. Online, acessed 1-12-2007.

18. KLH-Dalhousie University, (1992), Environmental Managemental Development in Indonesia, p.5-8, In Indonesia Environmental Soil Quality Criteria for Contaminated Site. Project of the Ministry States for Population and Environmental Republic of Indonesia and Dalhousie University Canada With Support form tha Canadian International Development Agency. 